\title{
TO THE ASSESSMENT OF VERTICAL CRANE LOAD
}

\author{
Sergii F. Pichugin, Yulia E. Patenko \\ Poltava National Technical Yuri Kondratyuk University, Poltava, UKRAINE
}

\begin{abstract}
The problems of analytical and statistical modeling of the travelling cranes loads are carried out in the paper. The analytical model was expanded by the consideration of influence of the approach of cranes trolley, consideration of zero realization areas and crane impact zones which allowed to precise the statistical characteristics of the vertical crane loads. The numerical modeling which takes into account the accidental position of the crane bridge and position of the trolley on the crane bridge was used for the calculation the vertical crane loads from the four-wheel cranes. Comparison of the results showed that the design value of the vertical load per wheel is rarely realized. This fact should be used to clarify the crane load combination factors.
\end{abstract}

Keywords: cranes loads, analytical model, numerical modeling, combination factor

\section{К ОЦЕНКЕ ВЕРТИКАЛЬНОЙ КРАНОВОЙ НАГРУЗКИ}

\begin{abstract}
С.Ф. Пичугин, Ю.Э. Патенко
Полтавский национальный технический университет имени Юрия Кондратюка, г. Полтава, УКРАИНА

Аннотация: В статье рассмотрены проблемы аналитического и статистического моделирования нагрузок мостовых кранов. Аналитическая модель была расширена за счет учета влияния сближения тележек кранов, учета областей нулевой реализации и зон воздействия кранов, что позволило уточнить статистические характеристики вертикальных крановых нагрузок. Численное моделирование, которое учитывает случайное положение мостового крана и положение тележки на мостовом кране, использовалось для расчета вертикальных нагрузок от воздействия четырехколесных кранов. Сравнение результатов показало, что расчетное значение вертикальной нагрузки на колесо реализуется редко. Этот факт следует использовать для уточнения коэффициента сочетания крановых нагрузок.
\end{abstract}

Ключевые слова: крановые нагрузки, аналитическая модель; численное моделирование, коэффициент сочетания

\section{INTRODUCTION}

The overhead travelling cranes which operate in real workshops transmit on the structures the complex loads. The determination of this loads by the full scale investigations in a real industrial building is very complicated due to the great complexity of tests. In this regard, statistical modeling of crane loads is justified for the clarification the reliability estimations of structures. Vertical loads from the influence of bridge cranes on the constructions under reallife conditions have a number of features, such as the close connection with the technological process of industrial buildings (IB), the specificity of the transmission on the structure, the dynamic nature, the probabilistic nature, etc. The paper considers some specific features of the realization of crane loads.

\section{ANALYSIS OF RECENT RESEARCHES AND PUBLICATIONS}

The problems of overhead travelling cranes actions which operate in the IB were examined in the monograph [1] and in work [2]. The detailed description of crane loads through the different probabilistic techniques were done in [3-5], where also the quantitative estimation of reliability of steel structures under crane loads were performed. Comparative analysis of 
different travelling crane producers was done in the paper [6].

Further development the probabilistic models and the calculation of numerical characteristics values from vertical and horizontal crane loads is done in [7]. The values of mathematical expectation, variance and standard for vertical and horizontal components of crane load were received analytically. The time factor, stochastic nature of loads and the strength of steel were taken into account to reveal an effect of different parameters (cranes capacity and mode of cranes, columns step, type of connection the column and girder, type of roofing, wind and snow loads) on the reliability of steel frameworks of IB $[8,9]$. A moderate number of random variables were taken into account in the work [10]. Notwithstanding, some random factors weren't taken into account. The random factors such as position of the crane bridge and position of the trolley on the crane bridge were considered in statistical modelling [11] where were suggested to include load combination factors into the calculation formulas using the temporary load with combinational value which should be reduced by the particular load combination factor for each new temporary load.

\section{INFLUENCE OF THE APPROACH OF CRANES TROLLEY}

In case of the permanent equipment placement in the workshop is unchanged, the vertical load can be determined taking into account the actual location of the crane maintenance zones and the actual approach of the trolley to the columns.

Vertical pressure of the crane wheel, could be calculated by:

$$
\tilde{F}\left[\frac{G_{c r}}{2}\left(\tilde{Q} G_{c r a b}\right) \frac{\tilde{a}}{L_{c r}}\right] \frac{1}{n_{0}},
$$

where $G_{c r}$ - weight of crane; $\tilde{Q}$ - accidental value of lifting capacity of crane; $G_{c r a b}$ - weight of crab; $\tilde{a}-$ accidental value of maximum closure of the crane hook to the column; $L_{c r}-$ crane span; $n_{0}$ - number of crane wheels.

The random pressure of the wheel $\tilde{F}$ is a function of two accidental arguments $\tilde{Q}$ and $\tilde{a}$, which are multiplied in (1). As a result, the distribution $f(\tilde{F})$ may vary depending on the distribution of the arguments $f(\tilde{Q})$ and $f(\tilde{a})$, and their correlation.

We will consider the distribution of the expression

$$
Z=X Y
$$

of random variables, one of which $X$ is distributed by the normal distribution law, another $Y$ - by the uniform law:

$$
\begin{array}{r}
f(X)=\frac{1}{\hat{X} \sqrt{2 \pi}} \exp \left[-\frac{X^{2}}{2 \widehat{X}^{2}}\right] \\
-\infty<X<\infty, \bar{X}=0 \\
f(Y)=\frac{1}{\beta-\alpha}, \propto \leq Y \leq \beta .
\end{array}
$$

The distribution function $F(z)$ is defined as:

$$
\begin{aligned}
& F(z)=P((X, Y) C D)= \\
& =\int_{(D)} \int f(X, Y) d X d Y .
\end{aligned}
$$

The domain of integration is in this case a band of width $\beta-\alpha$, which extends from $-\infty$ to the intersection with a hyperbola $Z=X Y$, at the same time the projection of the section of the intersection on the $X$ axis has a length $\frac{Z}{\beta}-\frac{Z}{\alpha}$.

$$
\begin{aligned}
& F(Z)=\int_{-\infty}^{Z / \beta} d X \int_{\propto}^{\beta} \frac{1}{\beta-\alpha} \frac{1}{\hat{X} \sqrt{2 \pi}} \exp \left(-\frac{X^{2}}{\hat{x}^{2}}\right) d y+ \\
& +\int_{-\infty}^{Z / \beta} d X \int_{\infty}^{i / X} \frac{1}{\beta-\alpha} \frac{1}{\hat{X} \sqrt{2 \pi}} \exp \left(-\frac{X^{2}}{2 \hat{X}^{2}}\right) d y .
\end{aligned}
$$

For $f(Z)=F(Z)$, after the reduction we obtain the expression: 


$$
\begin{gathered}
f(Z)=\frac{1}{\hat{X} \sqrt{2 \pi}(\beta-\alpha)} \times \\
\times \int_{\frac{z}{\beta}}^{Z / \alpha} \frac{1}{X} \exp \left(-\frac{X^{2}}{2 \hat{X}^{2}}\right) d X .
\end{gathered}
$$

a)

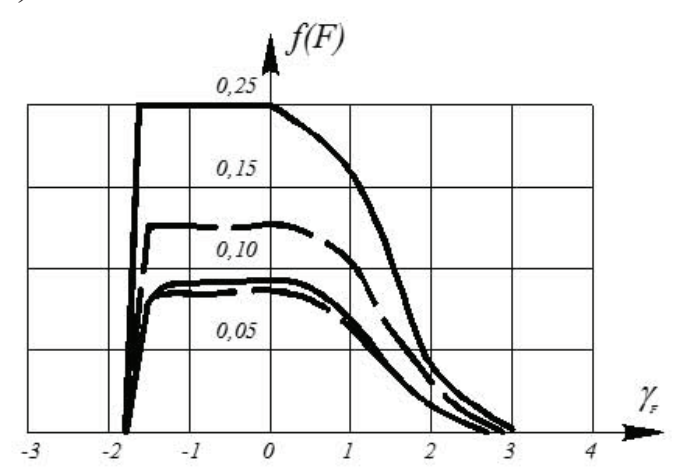

Using this expression for the vertical load (1), we obtain for the density of distribution:

$$
\begin{gathered}
f(F)=\frac{L_{c r} n_{0}}{\sqrt{2 \pi}(\beta-\alpha) \hat{F}} \times \\
\times \int_{b}^{a} \frac{1}{Q} \exp \left[-\frac{\left(Q-\bar{Q}-G_{T}\right.}{2 \hat{G}^{2}}\right] d Q .
\end{gathered}
$$

b)

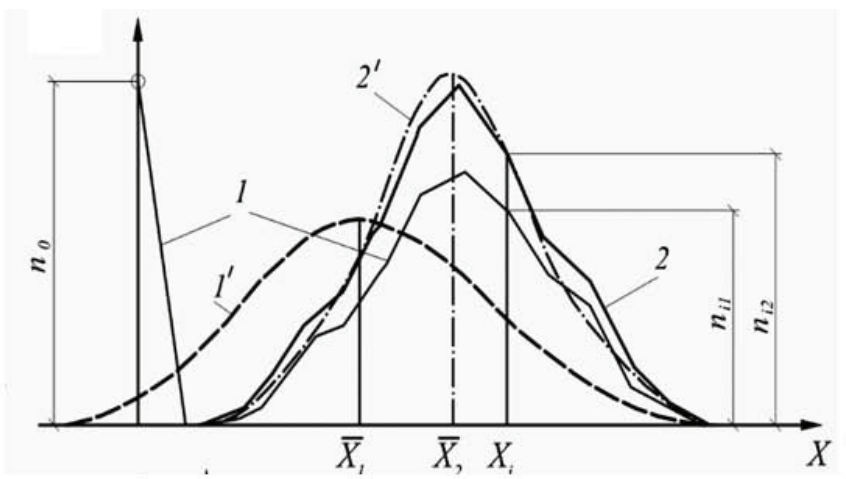

Figure 1. Distribution of vertical crane loads:

a) vertical pressure on a wheel of cranes of different load-carrying capacity;

b) ordinates of crane load processes.

Legend: 1 and 1 '-empirical and normal distributions for the process;

2 and $2^{\prime}$ - the same for a process without zeros.

Boundaries of integration:

$$
\begin{gathered}
a=\left(F-\frac{G_{M}}{2 n_{0}}\right) \frac{L_{c r} n_{0}}{\propto}-G_{T} \\
b=\left(F-\frac{G_{M}}{2 n_{0}}\right) \frac{L_{c r} n_{0}}{\beta}-G_{T} .
\end{gathered}
$$

An example of load distribution on a crane wheel, constructed according to the derived expression (4), is shown in Fig. 1, a.

On the basis of the theorem on the numerical characteristics of the product of random variables were determined:

- wheel pressure mathematical expectation:

$$
\bar{F}=\left[\frac{G_{M}}{2}+\left(\bar{Q} G_{T}\right) \frac{(\propto+\beta)}{2 L_{c r}}\right] \frac{1}{n_{0}} ;
$$

- wheel pressure standard:

$$
\begin{gathered}
\hat{F}=\hat{Q}^{2} \frac{(\beta-\alpha)^{2}}{12 L_{c r}{ }^{2} n_{0}{ }^{2}}\left(\bar{Q}+G_{T}\right)^{2} \times \\
\times \frac{(\beta+\alpha)^{2}}{12 L_{c r}{ }^{2} n_{0}{ }^{2}}+\frac{(\beta+\alpha)^{2}}{4 L_{c r}{ }^{2} n_{0}{ }^{2}} .
\end{gathered}
$$

The reducing coefficient for the taking into account the limitation of the trolley crane approach is proposed for the calculation the vertical load:

$$
l=\frac{F^{H}(p)}{F^{H}}
$$

where $F^{H}(p)$ and $F^{H}$ are the standard pressures with the same probability $[P]$, respectively, with the passport approaching to the considered range of columns $y_{0}$ and with the limitation of approaching $y_{\min }=y_{0}+p L_{c r}$. 
In case of impossibility of approaching to a range of columns at a distance $y_{\text {min }}$ actual and nominal load on the column and crane beam the considered row:

$$
\begin{gathered}
F_{\text {maxt }}^{\text {fact }}= \\
=\left[\frac{G_{c r}}{2}+\left(\frac{Q+G_{c r a b}}{0,5 n}\right) \frac{L_{c r}-y_{0}}{L_{c r}}\right] \sum Y ; \\
=\left[\frac{G_{c r}}{2}+\left(\frac{Q+G_{\text {max }}}{0,5 n}\right) \frac{L_{c r}-y_{\min }}{L_{c r}}\right] \sum Y,
\end{gathered}
$$

where $G_{c r}$ and $G_{c r a b}$ - respectively the weight of the crane and crab; $\mathrm{n}$ - number of wheels of the crane; $y_{0}-$ passport minimum trolley approximation to the row of columns considered; $\sum Y$ - the sum of the ordinates of the influence lines.

We designated the ratio

$$
k=\frac{Q+G_{T}}{G_{M}}
$$

and took into account the expression

$$
y_{\min }=y_{0}+p L_{c r}
$$

we obtained:

$$
l=1-\frac{p k L_{c r}}{2 L_{c r}+k\left(L_{c r}-y_{0}\right)} .
$$

It is considered that the statistical picture of the change of vertical loads with limited approach of cranes and in usual cases with the absence of approaches - remains unchanged. This assumption goes to the safety margin, which leads to an increase of the factor $l$ in comparison with the actual values. Expression (8) defines a minimum limit for reducing the vertical load and provides a significant reduction of loads in a number of cases (on average, the load is reduced by $10 \ldots 12 \%)$. The values of the coefficients $l=0,76 \ldots 0,94$ were recommended for practical calculations when $p=0,1 \ldots 0,4$.

\section{CONSIDERATION OF ZERO REALIZATION AREAS}

Realization of crane influences on a structure usually takes into account breaks in loading zero areas. Such character of loads influences on the numerical characteristics of crane loads. Below is shown the analytical approach to taking into account zero areas of implementation of vertical loads of bridge cranes.

In the case of statistical processing of continuous realization of crane loads, the stationary random process $\tilde{X}_{1}(t)$ is divided into time intervals $\Delta \mathrm{t}$, which gives, after framing, the bimodal distribution of the process ordinates, the estimation of the statistical mean $\bar{X}_{1}$ and the dispersion $\hat{X}_{1}$. The normal distribution constructed according to these characteristics does not correspond to the experimental distribution, therefore, it is interesting to pass to the random process $\tilde{X}_{2}(t)$ without zero sections with numerical characteristics $\bar{X}_{2}$ and $\bar{X}_{2}$, for which the ordinates of distribution are close to the normal law.

Thus, the detailed characteristics of the random process $\tilde{X}_{1}(t)$ for the vertical loads of bridge cranes with a flexible suspension were detailed:

$$
\begin{gathered}
\bar{X}_{1}=\left(1-n_{0}\right)(0,66-0,243 \eta) ; \\
X_{1}=\left(1-n_{0}\right) \times \\
\times\left[0,017++n_{0}(, 66-0,243 \eta)^{2}\right] ; \\
=\sqrt{\left(1-n_{0}\right)\left[0,017+n_{0}(, 66-0,243 \eta)^{2}\right]} .
\end{gathered}
$$

\section{CONSIDERATION OF THE CRANE IMPACT ZONES}

The value of $n_{0}$ may be considered as a possibility of the absence of a bridge crane in the considered zone of influence and defined as $n_{0}=1-p_{1}$, where $p_{1}-$ is the probability of a crane stay in the zone of influence under the condition of its operation. 


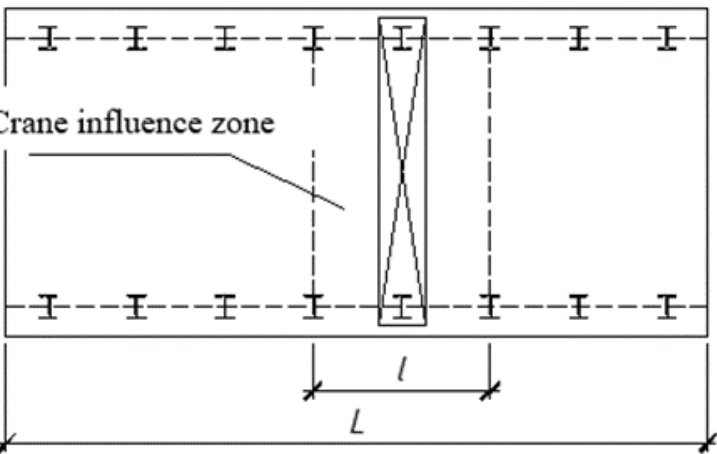

a)

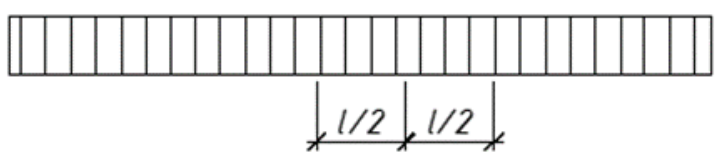

b)

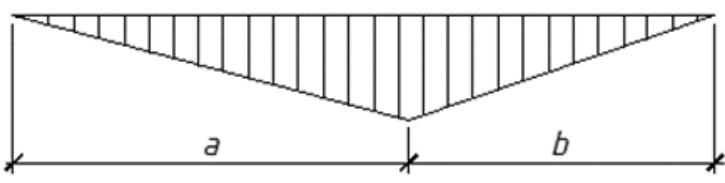

c)

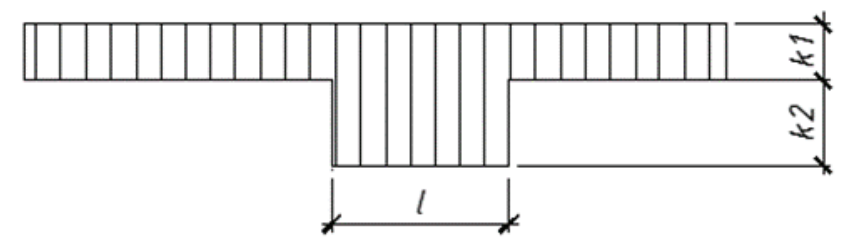

Figure 2. To determination of the probability of crane stay in the zone of influence:

a) 1-st scheme of intensity of work; b) 2-th scheme of intensity of work;

c) 3-rd scheme of intensity of work.

Value $p_{1}$ depends on the peculiarities of the technological process in the span of the IB. The three schemes of intensity of work of bridge cranes practically completely cover possible technological situations in spans, shown in Fig. 2. The first scheme - is described by a uniform distribution (Fig. 2, a). In this case, the probability of staying the crane in the zone of influence is defined as $p_{1}=l / L$, where $l$ - the length of the zone of influence; $L$ - total length of the crane zone.

Then the frequency of zero load values is defined as:

$$
n_{0}=1-\frac{l}{L}=\frac{L-l}{L}
$$

The second scheme is described by a triangular distribution (Fig. 2, b). The probability of a crane stay in the zone of influence is determined as follows:

Then the expression for the desired frequency will look like:

$$
n_{0}=\frac{b(a+0,5 l)^{2}+a(b+0,5 l)^{2}}{a L} .
$$

If $a=b=0,5 l$ the values $p_{1}$ and $n_{0}$ will be follows:

$$
p_{1}=2 \frac{l}{L}-\left(\frac{l}{L}\right)^{2}, \quad n_{0}=\frac{(L-l)^{2}}{L^{2}}
$$

The third scheme is described by a uniform distribution, and the intensity of the technological process in the zone of influence is $k$ times higher than outside (Fig. 2, c). Ordinaries of density on areas are: 


$$
\begin{gathered}
k_{1}=\frac{1}{(k+1)(L-l)} ; \\
k_{2}=\frac{k}{l(1+k)} .
\end{gathered}
$$

Thereby the probability of a crane in the zone of influence is:

$$
p_{1}=k_{2} l=\frac{k}{1+k}
$$

Then the frequency is:

$$
n_{0}=k_{1}(L-l)=\frac{1}{1+k} .
$$

\section{NUMERICAL MODELLING OF CRANE LOADS}

Recent numerical studies [11] have shown that these combination factors of loads are too high. Due to the low probability of implementing the most disadvantageous position of all bridge cranes with maximum loads, it is possible to reduce the combination factors of efforts.

Modern programs allow to take into account many variables. Such an approach is realized by prof. A.V. Perelmuter in the development of a load calculation program [11]. This program was used for the calculations the loads of bridge cranes with a payload of $32 / 16,5$ t. Accidental values for each of the bridge cranes were:

- the position of the cranes on the crane girders;

- the load weight;

- the position of the trolleys on the bridge of the crane.

The distributions obtained by the modelling were close to the distributions constructed by the analytical method (Fig. 1, a). Load values were calculated at different positions of the crane with different weight of the load (Fig. 3, items 1-6):

- 1 - a crab without a load near the right range of columns;

- 2 - a crab with a load, near the right range;

- 3 - a crab without a load, near the left range;
- 4 - a crab with a load, located in the middle of the span;

- 5 - a crab with a load, near the left range, the weight is equal to the average load-carrying capacity Qav;

- 6 - a crab with a load near the left range, the weight is Qav + 2.5Qst (Qst - the standard load-carrying capacity);

- 7 - a crab with a weight, near the left range, the weight is Qav + 3.5Qst.

The polygons of vertical loads on the crane wheel, normalized by the value $Q+G_{c r}+G_{c r a b}$, showed that most of the values of the polygon are concentrated between the estimated values of positions 2 and 4 (Fig. 3). The characteristic value of the vertical load, calculated in accordance with the requirements of the norms DBN [12] (position 5), is in the zero zone, that shows, the characteristic value is rarely realized.

In addition, the vertical loads on the column of the IB with span $22,5 \mathrm{~m}$ were numerically modeled. The length of the building is 120 meters, the span of crane girder is 6 meters. Crane base is 5,1 meters, the overall dimension of crane is 6,3 meters, minimum approach to the column is 1,5 meters. The polygons of vertical loads on the crane wheel and the column of the IB which were received by the numerical modelling (Fig. 2) are similar to the above-described distributions of the ordinates of crane load processes with zero zones (Fig. 1, b):

- Cr 1 Fnom - vertical load on the crane wheel;

- $\mathrm{Cr} 1 \mathrm{~N}$ - vertical load on the column from the influence of one crane;

- Cr $2 \mathrm{~N}$ - vertical load on the column from the influence of two cranes;

- Cr 2 N2 - vertical load on the column from the influence of four cranes.

The comparative loads were put on the abscissa axis. The comparative loads are the modelling loads (q) which were divided by the design load values $\left(\mathrm{q}_{\mathrm{d}}\right)$. The ordinate axis was trimmed for the better visualization. 


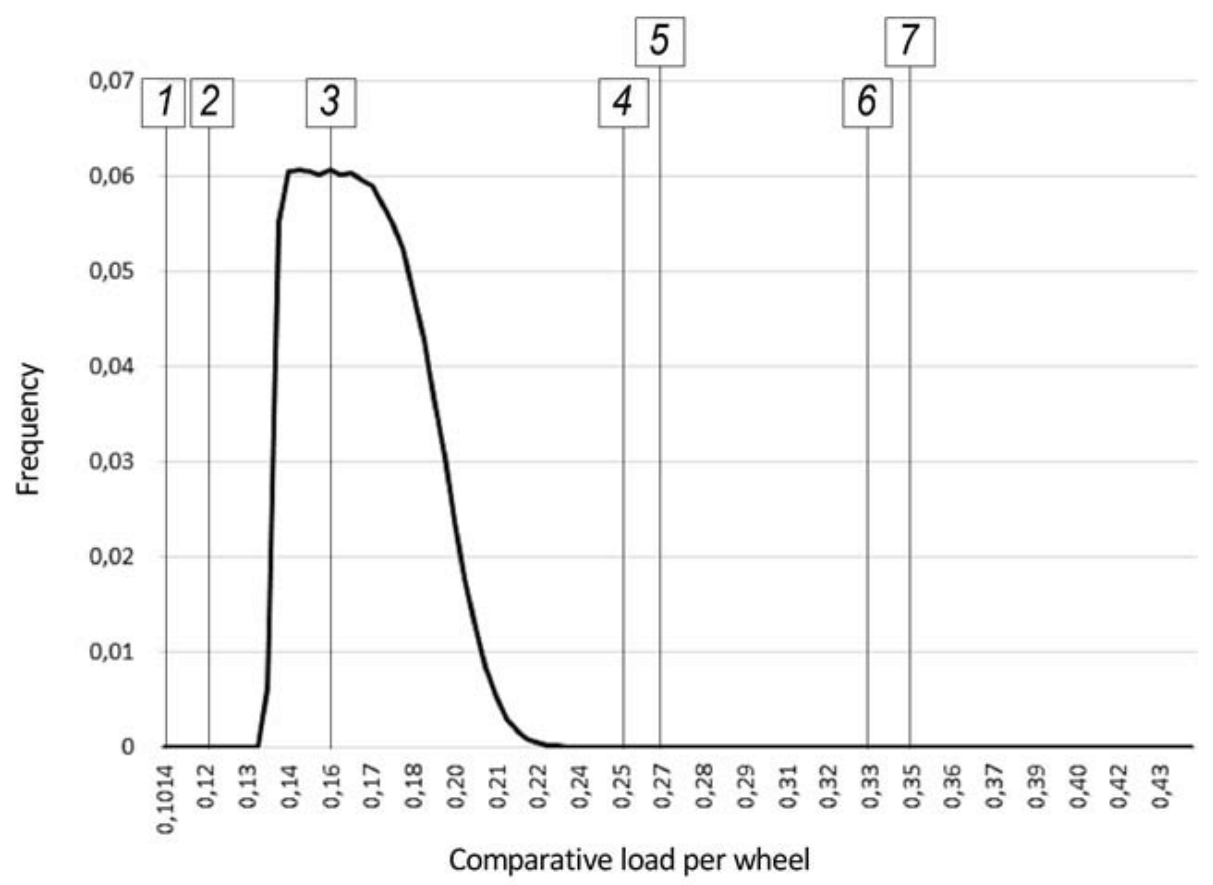

Figure 3. Polygon of the vertical loads on the wheel.

The resulting vertical load on the crane wheel (Fig. 4) are within the range of $0,4 \ldots 0,6$ of the calculated load, while the loads on the column from one, two and four cranes have values from
0 to 0,4 of the calculated load on column. The greater part of the vertical load on the column (up to $87 \%$ of the tests) have zero values.

Relative load, $\mathrm{q} / \mathrm{q}_{0}$

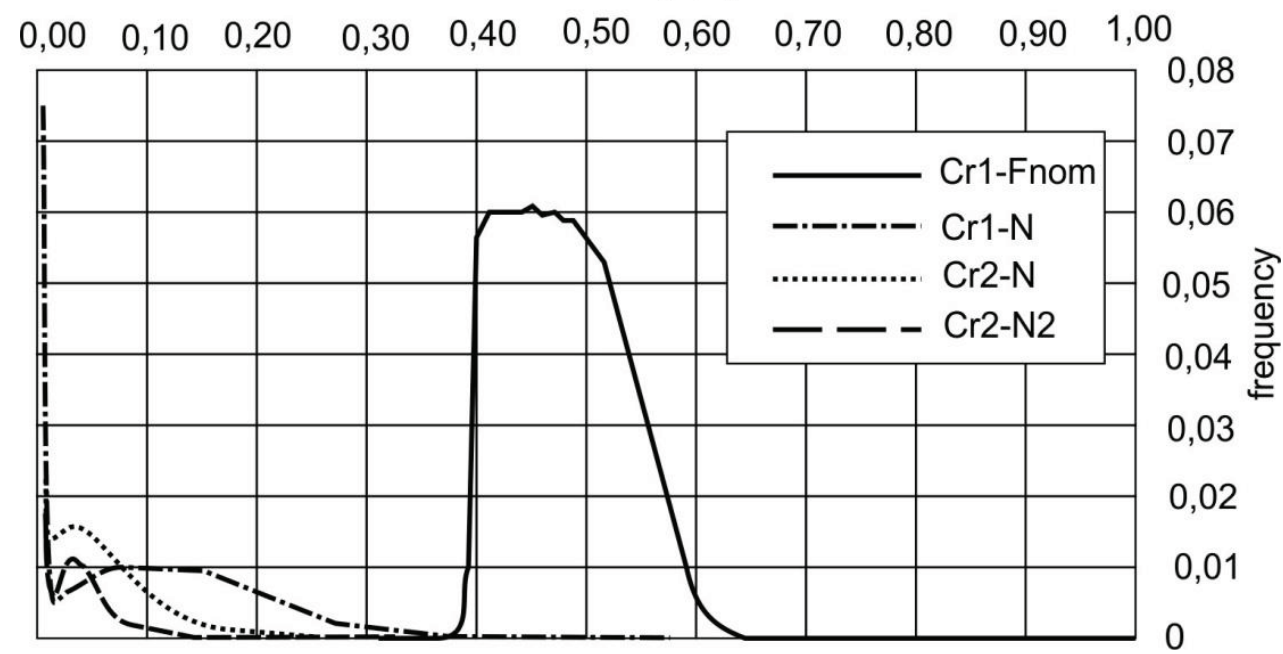

Figure 4. Vertical loads polygons on the wheel and on the IB column.

\section{CONCLUSIONS}

Due to the great difficulty of experimental investigations of the crane loads, which have the complicated statistical nature, it is possible to consider analytically such special features of these loads as a trolley approximation, zero crane operation zones and crane impact zones. Nowadays statistical computer modelling can take into account a greater number of variable 
parameters (position of the cranes in the span, position of the crab on the bridge crane, crane position relative to each other). Comparison of polygons of vertical load on the crane wheel with the analytical results showed that design value of load, calculated according codes DBN realizes very rarely. The further numerical modeling of loads arises an interest for obtaining a more precise definition of the load combination factors and efforts in the structures of industrial buildings.

\section{REFERENCES}

1. Pichugin S.F. Kranovyye Nagruzki na Stroitel'nyye Konstruktsii [Crane Loads on Building Structures]. Poltava, OOO "ASMI", 2014 (in Russian).

2. Gordeyev V.N., Lantukh-Lyashchenko A.I., Makhin'ko A.V., Pashinskiy V.A., Perel'muter A.V., Pichugin S.F. Nagruzki i Vozdeystviya na Zdaniya i Sooruzheniya [Loads and Impacts on Buildings and Structures]. Moscow, SCAD Soft, ASV, 2011, 514 pages (in Russian).

3. Pichugin S.F., Demchenko N.A. Reliability of Crane Loads. Poltava, PNTU, 2005, 91 pages.

4. Pichugin S. Analysis of Bridge Crane Loads on Industrial Buildings. // XLIV Konferencja Naukowa KILiW PAN i KN PZITB, Tom 7, Poznan-Krynica, 1998, pp. 171-178.

5. Pichugin S. Probabilistic Description of Crane Load on Building Structures. // XLIII Konferencja Naukowa KILiW PAN i KN PZITB, Tom III, Poznan-Krynica, 1997, pp. 171-178.

6. Pichugin S.F., Patenko Iu.E., Maslova S.A. Comparative Analysis of Loads from the Travelling Cranes of Different Producers. // International Journal of Engineering and Technology, 2018, Vol. 7 (3.2), pp. 36-39.

7. Pichugin S.F., Patenko Iu.E., Maslova S.A. Probabilistic Numerical Characteristics of Loads of Overhead
Cranes on Framewokrs of Industrial Buildings. // Academic Journal. Series: Industrial Machine Building, Civil Engineering, 2018, Vol. 1(50), pp. 62-68.

8. Pichugin S. Reliability Estimation of Steel Elements under Variable Loads. // XLI Konferencja Naukowa KILiW PAN i KN PZITB. "Krynica 1995", Tom 3, KrakowKrynica, 1995. pp. 151-156.

9. Pichugin S.F., Patenko Iu.E. Reliability of Steel Frameworks of Industrial Buildings. // METNET International Seminar, 11-12 October, 2017, Cottbus, Germany, 2018, pp. 83-93.

10. Pasternak H., Rozmarynowski B., Wen Y.-K. Crane Load Modelling. // Structural Safety, 1996, Vol. 17, pp. 205-224.

11. Perel'muter A.V. Statisticheskoye Modelirovaniye Kranovykh Nagruzok i Raschetnyye Sochetaniya Usiliy [Crane Loads Statistical Modelling and Design Combinations of the Internal Forces]. // International Journal for Computational Civil and Structural Engineering, 2017. Volume 13, Issue 2, pp. 136-144 (in Russian).

12. DBN V.1.2-2:2006. Navantazhennya i vplyvy: [Chynnyy vid 2007-01-01] / Minbud Ukrayiny. Kiev, Vyd-vo "Stal", 2006, 60 pages.

\section{СПИСОК ЛИТЕРАТУРЫ}

1. Пичугин С.Ф. Крановые нагрузки на строительные конструкции. - Полтава: ООО «АСМИ», 2014.

2. Гордеев В.Н., Лантух-Лященко А.И., Пашинский В.А., Перельмутер А.В., Пичугин С.Ф. Нагрузки и воздействия на здания и сооружения. - Москва, SCAD Soft, ACВ, ДМК Пресс, 2011. $514 \mathrm{c}$.

3. Pichugin S.F., Demchenko N.A. Reliability of Crane Loads. Poltava, PNTU, 2005, 91 pages.

4. Pichugin S. Analysis of Bridge Crane Loads on Industrial Buildings. // XLIV 
Konferencja Naukowa KILiW PAN i KN PZITB, Tom 7, Poznan-Krynica, 1998, pp. 171-178.

5. Pichugin S. Probabilistic Description of Crane Load on Building Structures. // XLIII Konferencja Naukowa KILiW PAN i KN PZITB, Tom III, Poznan-Krynica, 1997, pp. 171-178.

6. Pichugin S.F., Patenko Iu.E., Maslova S.A. Comparative Analysis of Loads from the Travelling Cranes of Different Producers. // International Journal of Engineering and Technology, 2018, Vol. 7 (3.2), pp. 36-39.

7. Pichugin S.F., Patenko Iu.E., Maslova S.A. Probabilistic Numerical Characteristics of Loads of Overhead Cranes on Framewokrs of Industrial Buildings. // Academic Journal. Series: Industrial Machine Building, Civil Engineering, 2018, Vol. 1(50), pp. 62-68.

8. Pichugin S. Reliability Estimation of Steel Elements under Variable Loads. // XLI Konferencja Naukowa KILiW PAN i KN PZITB. "Krynica 1995", Tom 3, KrakowKrynica, 1995. pp. 151-156.

9. Pichugin S.F., Patenko Iu.E. Reliability of Steel Frameworks of Industrial Buildings. // METNET International Seminar, 11-12 October, 2017, Cottbus, Germany, 2018, pp. 83-93.

10. Pasternak H., Rozmarynowski B., Wen Y.-K. Crane Load Modelling. // Structural Safety, 1996, Vol. 17, pp. 205-224.

11. Перельмутер A.B. Статистическое моделирование крановых нагрузок и расчетные сочетания усилий. // International Journal for Computational Civil and Structural Engineering / Международньй журнал по расчету гражданских и промышленных конструкиий, 2017. Volume 13, Issue 2, pp. 136-144.

12. ДБН В.1.2-2:2006 Навантаження i впливи [Чинний від 2007-01-01]. Мінбуд
України. - К. : Вид-во «Сталь», 2006. $60 \mathrm{c}$.

Sergii F. Pichugin, Doctor of Sciences, Professor, Head of the Department of Metal, Wooden and Plastic Structures; Poltava National Technical Yuri Kondratyuk University; 36011, Ukraine, m. Poltava, Pershotravnevyj Ave. 24, phone: +3805325 61604; e-mail:vstup@pntu.edu.ua.

Yulia E. Patenko, Candidate of Technical Sciences, Associated Professor, Department of Descriptive Geometry and Graphics; Poltava National Technical Yuri Kondratyuk University; 36011, Ukraine, m. Poltava, Pershotravnevyj Ave. 24, phone: +380 5325 61604;

E-mail: vstup@pntu.edu.ua.

Пичугин Сергей Федорович, доктор технических наук, профессор, заведующий кафедрой конструкций из металла, дерева и пластмасс; Полтавский национальный технический университет имени Юрия Кондратюка; Першотравневий проспект, 24, Полтава, Полтавська область, Украина, 36000; тел. +380 5325 61604; e-mail: vstup@pntu.edu.ua.

Патенко Юлия Эдуардовна, кандидат технических наук, доцент кафедры начертательной геометрии и графики; Полтавский национальный технический университет имени Юрия Кондратюка; Першотравневий проспект, 24, Полтава, Полтавська область, Украина, 36000; тел. +380 5325 61604;

E-mail: vstup@pntu.edu.ua. 